\title{
If registered, fungicide could reduce cavity spot of carrots
}

\author{
R. Michael Davis \\ Elisabetta Vivoda \\ - Joe J. Nuñez \\ 口 \\ a John P. Guerard
}

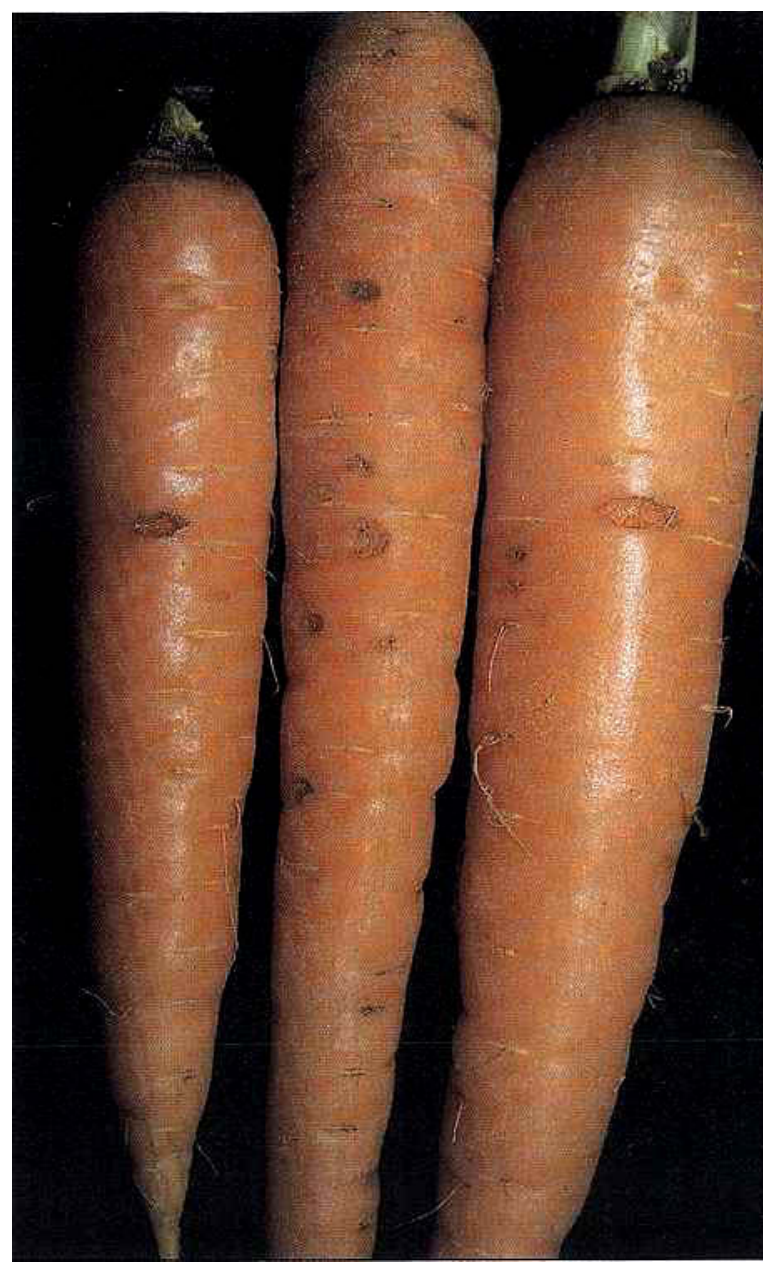

Cavity spot lesions reduce carrot quality. ai/acre. The $5 \mathrm{G}$ formulation was spread in the planting furrow, and the $2 \mathrm{E}$ formulation was sprayed on the surface of the soil or over. the carrots before an irrigation. Six 30-footlong replications were arranged in a randomized complete block design.

All the carrots in 3 feet of row from each plot (about 115 carrots for each 3-footsample) were harvested at maturity, washed, weighed, and examined for cavity spots. Results were expressed as the percentage of carrots with cavity spot lesions. The experiment was conducted in two commercial fields in 1987 and in one in 1988. All fields were sprinkler-irrigated.
In another experiment, single applications of $2 \mathrm{Ib}$ ai of metalaxyl per acre were applied either 43 or 53 days after planting in one field, and 49 or 59 days after planting in another field.Singleapplications of metalaxyl at $1 \mathrm{lb}$ ai/acre were also applied $15,30,45,60$, or 75 days after planting in an additional trial. Treatments were replicated as previously described.

Metalaxyl significantly reduced the incidence of cavity spot in all trials (table 1). In

Europe showed that Pythium species, especially $P$. violae, were associated with cavity spot lesions. The purpose of our study was to determine the cause and control of cavity spot of carrots in the San Joaquin Valley.

To isolate potential pathogens, we collected tissue from the margin of cavity spot lesions on carrots in Kern County fields, placed samples aseptically on a medium selective for $P$ ythium and related fungi (corn meal agar plus antibiotics) and on various standard media for the isolation of bacteria and other fungi. These isolations yielded $P$. violae and, less frequently, $P$. ultimum. No other organisms were recovered with any consistency. In controlled greenhouse tests, all the carrots grown in soil inoculated with $P$. violae and $65 \%$ of carrots grown in soil inoculated with $P$. ultimum developed typical cavity spot lesions. Both fungi were subsequently recovered from lesions plated on corn meal agar.

\begin{tabular}{|c|c|c|c|}
\hline & \multicolumn{3}{|c|}{ Percentage of carrots with cavity spots } \\
\hline & Trial 1 & Trial 2 & Trial 3 \\
\hline \multicolumn{4}{|l|}{ Metalaxyl, Ibs a.i./acre } \\
\hline Preplant, $1.0 \mathrm{lb}$ & 24.1 & 7.3 & 29.5 \\
\hline Preplant, $2.0 \mathrm{lb}$ & 20.5 & 2.1 & 27.3 \\
\hline Preplant, $4.0 \mathrm{lb}$ & 7.9 & 2.1 & 20.8 \\
\hline \multicolumn{4}{|l|}{ Split-postplant, } \\
\hline $0.125 \mathrm{lb}$ & & & \\
\hline $\begin{array}{l}\text { (8 appl., } 1.0 \mathrm{lb} \text { total) } \\
\text { Solit-postplant. }\end{array}$ & 7.6 & 1.2 & 25.4 \\
\hline \multicolumn{4}{|l|}{$\begin{array}{l}\text { Split-postplant, } \\
0.25 \mathrm{~kb}\end{array}$} \\
\hline (8 appl., $2.0 \mathrm{lb}$ total) & 0.9 & 2.7 & 21.8 \\
\hline None & 59.5 & 39.7 & 36.7 \\
\hline \multicolumn{4}{|c|}{ Mean squares for selected contrasts } \\
\hline Metalaxyl vs. none & $5,896.0^{\star}$ & $4,489.0^{\circ}$ & $369.8^{\star}$ \\
\hline Preplant vs. split & $1,057.6^{*}$ & 112.3 & 40.1 \\
\hline Preplant, $1.1+2.2$ vs split & $1,710.3^{*}$ & 162.2 & $148.0^{\circ}$ \\
\hline Preplant, 4.5 vs. split & 26.5 & 8.4 & 32.5 \\
\hline Split, 1.1 vs. split, 2.2 & $467.6^{*}$ & 10.1 & 4.8 \\
\hline Preplant, linear & $3,936.8^{\star}$ & $2,522.6^{*}$ & $498.3^{*}$ \\
\hline
\end{tabular}


Table 2. Etficacy of a single postplant application of metalaxyl on the control of cavity spot

\begin{tabular}{|c|c|c|}
\hline & \multicolumn{2}{|c|}{$\begin{array}{l}\text { Percentage of carrots } \\
\text { with cavity spots }\end{array}$} \\
\hline & Trial 1 & Trial 2 \\
\hline \multicolumn{3}{|l|}{ Metalaxyl (2 lbs a.i./acre) } \\
\hline None & $33.8 \mathrm{a}$ & $29.6 a$ \\
\hline 43 days after planting & $3.8 \mathrm{~b}$ & - \\
\hline 49 days after planting & - & $10.8 \mathrm{~b}$ \\
\hline 53 days after planting & $7.8 \mathrm{~b}$ & - \\
\hline 59 days after planting & - & $13.1 \mathrm{~b}$ \\
\hline LSD, $\mathrm{P}=0.05$ & 6.9 & 9.0 \\
\hline
\end{tabular}

two trials, metalaxyl almost completely eliminated the disease. In two of the three trials, the control achieved with a seasonal total of 1 or $2 \mathrm{lb}$ ai of metalaxyl per acre in split applications was significantly greater than was achieved with the single preplant application of 1 or $2 \mathrm{lb}$. However, there was nosignificant difference between the efficacy of the split applications and the efficacy of a single preplant application of metalaxyl at 4 $\mathrm{lb}$ ai/acre. There was a significant negative correlation between the rate of metalaxyl applied preplant and the percentage of carrots with cavity spot lesions. There were no significant differences in disease control with thedifferent metalaxyl formulations $(5 \mathrm{G}$ and 2E). Carrot yields were not influenced by metalaxyl applications or cavity spot incidence.

Single applications of metalaxyl at $2 \mathrm{lb}$ ai/acre applied $40+$ or $50+$ days after planting also significantly reduced the incidence of cavity spot (table 2). We have other data indicating that single applications of metalaxyl at $1 \mathrm{lb}$ ai/acre applied at different times during the season failed toreduce the incidence of cavity spot.

\section{Conclusions}

Pathogenicity tests and field trials with metalaxyl, which is active only on Pythium and related fungi, demonstrated the cavity spot on carrots in California is caused by Pythium species. BothP. violae and P. ultimum caused cavity spot lesions in controlled conditions, but $P$. violae was the more virulent fungus on carrots.

Metalaxyl is not currently registered in California for use on carrots, but it shows promise as an effective tool for reducing losses to cavity spot. In our study, soil drenches of metalaxyl applied 40 to 60 days afterplanting or multiple, diluteapplications throughout the season weremoreefficacious than single preplant applications at comparable rates.

Michael Davis is Extension Plant Pathologist, and Joe J. Nuñez is Staff Research Associate, Department of Plant Pathology, UC Davis; John $P$. Guerard is Farm Advisor, Kern County; and Elisabetta Vivoda is Graduate Student, Department of Plant Pathology, UC Davis. Research was funded by a grant from the California Fresh Carrot Advisory Board.
Phylloxera on rise...

\section{Deadly insect pest poses increased risk to north coast vineyards}

\author{
Jeffrey Granett $\quad \square \quad$ John A. De Benedictis $\square \quad$ James A. Wolpert \\ Edward Weber $\square$ Austin C. Goheen
}

Resistant rootstocks protect grape vines from phylloxera; however, a new form of this insect, Biotype $B$, threatens the survival of $70 \%$ of Napa and Sonoma County vineyards, those which are planted on the rootstock AxR\#1. Research demonstrates that different accessions of AxR\#1 are equally susceptible to damage by this insect, a form of plant lice. The insect has spread from two sites in 1983 to more than 70 sites in those two counties; spread to other grapegrowing counties is likely.
Grape phylloxera is a widespread pest of grapevines. Native toeasternNorth America, it was introduced into Europe in the 1860s where it devastated vineyards. In response, European researchers developed resistant rootstocks. Many rootstocks available today are a result of breeding and selections made in Europe during the last quarter of the 19th century. One of these, Ganzin 1, known in California as AxR\#1, was initially successful. However, in both Europe and South Africa, resistance disappeared after a number of years. The loss of resistance was attributed to a more virulent race of phylloxera.

Phylloxerabecameanimportant problem in California with the introduction of the European grape, Vitis vinifera. Trials to determine which rootstocks were suited to

\section{growing counties is likely.}

TABLE 1. Grape phylloxera utilization of Cabernet Sauvignon and two AxR\#1 accessions

\begin{tabular}{|c|c|c|c|c|c|c|}
\hline \multirow{2}{*}{$\begin{array}{l}\text { Root } \\
\text { type }\end{array}$} & \multicolumn{2}{|c|}{$\begin{array}{l}\text { Percent surviving } \\
\text { to maturity }\end{array}$} & \multicolumn{2}{|c|}{$\begin{array}{c}\text { Developmental } \\
\text { time }\end{array}$} & \multicolumn{2}{|c|}{ Fecundity } \\
\hline & Mean ${ }^{\star}$ & $\mathrm{N}+$ & Mean & $\mathrm{N}$ & Mean & $\mathrm{N}$ \\
\hline & $\%$ & & days & & ffemale & \\
\hline
\end{tabular}

Colony I ( 2 replications) biotype $A$ standard

$\begin{array}{llllllr}\text { Cabernet } & 54.4 \mathrm{a} & 160 & 25.3 \mathrm{a} & 87 & 4.8 \mathrm{a} & 285 \\ \text { Sauvignon } & 15.9 \mathrm{~b} & 170 & 48.0 \mathrm{~b} & 27 & 1.7 \mathrm{~b} & 78 \\ \text { AxR1-01A } & 19.5 \mathrm{~b} & 200 & 39.8 \mathrm{~b} & 39 & 1.7 \mathrm{~b} & 126 \\ \text { AxR1-05 } & 126 & & \end{array}$

Colony II (1 replication) previously tested as biotype $A$

$\begin{array}{lllllll}\text { Cabernet } & 48.7 \mathrm{a} & 80 & 29.2 \mathrm{a} & 39 & 5.0 \mathrm{a} & 118 \\ \text { Sauvignon } & 18.7 \mathrm{~b} & 80 & 39.8 \mathrm{a} & 15 & 4.4 \mathrm{a} & 47 \\ \text { AxR1-01A } & 43.3 \mathrm{a} & 60 & 33.5 \mathrm{a} & 26 & 4.8 \mathrm{a} & 92 \\ \text { AxR1-05 } & & & \end{array}$

Colony III (1 replication) biotype B standard

$\begin{array}{lllllll}\text { Cabernet } & 52.5 \mathrm{a} & 40 & 26.7 \mathrm{a} & 21 & 6.0 \mathrm{a} & 70 \\ \begin{array}{l}\text { Sauvignon } \\ \text { AxR1-01A }\end{array} & 22.5 \mathrm{~b} & 40 & 29.3 \mathrm{a} & 9 & 4.6 \mathrm{a} & 22 \\ \text { AxR1-05 } & 18.3 \mathrm{~b} & 60 & 31.0 \mathrm{a} & 11 & 6.9 \mathrm{a} & 36\end{array}$

Colony IV ( 3 replications) biotype B

$\begin{array}{|lllllll|}\text { Cabernet } & 48.7 \mathrm{a} & 300 & 27.6 \mathrm{a} & 146 & 5.1 \mathrm{a} & 484 \\ \text { Sauvignon } & & & & & & 214 \\ \text { AxR1-01A } & 25.0 \mathrm{~b} & 280 & 29.4 \mathrm{a} & 70 & 7.5 \mathrm{a} & 326 \\ \text { AxR1-05 } & 30.7 \mathrm{~b} & 300 & 30.3 \mathrm{a} & 92 & 6.7 \mathrm{a} & \end{array}$

Means in the same colony and column followed by different letters are significantly different $(P<0.05)$. $\dagger \mathrm{N}$ is the number of animals from which means were calculated. 